\title{
Partisipasi Politik Masyarakat Adat Baduy dan Implikasinya terhadap Representasi Politik: Kepentingan Adat yang Tersisih
}

\section{Political Participation of Baduy Indigenous Peoples and Their Implications for Political Representation: Marginalized Indigenous Interests}

\author{
Mahpudin \\ Jurusan Politik Pemerintahan, Universitas Gadjah Mada \\ Bulaksumur, Caturtunggal, Kec. Depok, Kabupaten Sleman, Daerah Istimewa Yogyakarta \\ 55281 \\ *corresponding author E-mail: mahpudin95@mail.ugm.ac.id
}

Diterima: 15 Juli 2020; Direvisi: 23 Juli 2020; Disetujui: 26 Juli 2020

\begin{abstract}
ABSTRAK
Artikel ini membahas tentang partisipasi politik masyarakat adat Baduy dan implikasinya terhadap representasi politik. Kajian ini menjadi penting sebab partisipasi masyarakat Baduy tidak bisa dilepaskan dari struktur adat yang mengatur cara mereka berpolitik. Sementara, representasi politik masyarakat adat menjadi krusial di tengah hadirnya krisis representasi pada lembaga politik formal melalui kontestasi elektoral. Artikel ini menggunakan jenis penelitian kualitatif dengan pendekatan case study. Proses pengumpulan data dilakukan melalui studi literatur. Menggunakan konteks pemilu legislatif pada tahun 2009 dan 2014 sebagai tool untuk menjelaskan partisipasi politik warga Baduy dalam pemilu. Saya berargumen bahwa partisipasi politik masyarakat adat baduy tidak berkorelasi terhadap bekerjanya ide representasi substansial. Representasi formal melalui proses elektoral tidak memberi dampak yang signifikan bagi kepentingan masyarakat Baduy. Warga Baduy tidak direpresentasikan oleh partai maupun kandidat di parlemen baik secara simbolik maupun substantif.
\end{abstract}

Kata Kunci: Masyarakat Adat Baduy, Partisipasi Politik, Pemilu Representasi Politik.

\begin{abstract}
This article examines the political participation of Baduy indigenous peoples and their implications for political representation. This study is important because political participation of Baduy peoples cannot be separated from the traditional structure that regulates the way they are involved in politics. Meanwhile, the political representation of Baduy peoples becomes crucial in the presence of a crisis of representation in formal political institutions through electoral contestation. Using the context of the 2009 and 2014 legislative elections as a tool to explain the political participation of Baduy peoples in elections, I argue
\end{abstract}

POLITICON VOL.2 No.2 2020 
that the political participation of the Baduy indigenous people does not correlate with the work of the idea of substantial representation. Formal representation through the electoral process did not have a significant impact on the interests of the Baduy people. Baduy residents are not represented by parties or candidates in parliament both symbolically and substantively.

Keywords: Baduy Indigenous Peoples, Political Participation, Elections Political Representation.

\section{PENDAHULUAN}

Dalam demokrasi elektoral, partisipasi politik dalam pemilu menjadi penting sebagai indikator untuk mengukur seberapa besar tingkat legitimasi warga negara terhadap pemerintahan yang terpilih melalui kontestasi elektoral (Andiraharja, 2020). Asumsinya, semakin tinggi tingkat partisipasi warga negara dalam pemilu, maka partai atau kandidat dianggap legitimate (Heywood, 2014). Sementara itu, diskursus tentang representasi politik merupakan jantung dari demokrasi perwakilan yang membahas bagaimana representator dalam hal ini partai atau calon kandidat yang terpilih dalam pemilu melakukan tindakan politik mewakili kepentingan konstituen mereka melalui sejumlah kebijakan atau memperjuangkan program tertentu (LestonBandeira, 2012; Pitkin, 1967). Karena itu, artikel ini coba memadukan kedua konsep tersebut antara partisipasi politik dalam pemilu dan implikasinya terhadap representasi politik dengan mengambil kasus masyarakat adat Baduy. Bagaimana partisipasi politik masyarakat adat Baduy dalam pemilu dan apa implikasinya terhadap representasi politik adalah dua pertanyaan kunci yang coba dijawab dalam artikel ini.

Diskursus tentang partisipasi politik dalam pemilu pada masyarakat adat Suku Baduy dipilih karena beberapa pertimbangan. Pertama, masyarakat adat Baduy merupakan masyarakat minoritas di Kabupaten Lebak, Banten. Secara kuantitas, jumlah penduduk di Kabupaten Lebak pada tahun 2017 sebanyak 1.288.103 jiwa, sementara suku Baduy yang terletak di Desa Kanekes, Kecamatan Leuwidamar hanya sekitar 11.699 jiwa (Lebakkab.bps.go.id, 2018). Artinya, eksistensi populasi masyarakat Suku Baduy hanya 0,9 \% dari seluruh jumlah populasi penduduk di Kabupaten 
Lebak, Banten. Selain itu, mereka memiliki cara pandang yang berbeda dengan masyarakat umumnya dalam berpolitik dan menjalani kehidupan sehari-hari yang masih kental dengan unsur adat. Seperti memilih untuk mengasingkan diri dari perkembangan dunia luar dan menetap hidup di kawasan pedalaman hutan.

Kedua, partisipasi politik masyarakat adat Baduy tidak bisa lepas dari pengaruh struktur adat yang mengatur cara mereka berpolitik praktis (Kurnia, Sihabudin, \& Yustianti, 2010). Ketiga, dalam setiap perhelatan kontestasi elektoral, partisipasi memilih masyarakat adat Baduy cenderung sangat rendah. Meskipun terjadi trend peningkatan jumlah pemilih yang datang ke TPS setiap periode pemilu, namun persentasenya tidak pernah lebih dari $60 \%$ dari keseluruhan jumlah daftar pemilih tetap (Dahlan, 2019). Keempat, sebagai konsekuensi dari tiga poin tersebut menyebabkan ide representasi yang dijalankan oleh partai atau kandidat atas nama kepentingan masyarakat adat Baduy mengalami hambatan sehingga upaya untuk membangun political linkage antara masyarakat Baduy dan struktur politik formal (partai atau pemerintah) menjadi sulit.

Terdapat beberapa kajian yang membahas tentang partisipasi politik masyarakat adat Baduy dalam demokrasi elektoral. Namun dari kajian yang ada lebih banyak menempatkan partisipasi politik masyarakat adat Baduy dari sudut pandang kultural. Dimana struktur adat mempengaruhi bagaimana masyarakat berpolitik dan menentukan pilihan terhadap partai maupun calon kandidat tertentu. Keberadaan lembaga adat yang dikepalai oleh seorang Puun dan Jaro Pamarentah sangat strategis dalam mengatur masyarakat adat agar tetap menjalankan aturan adat, termasuk ketika perhelatan pemilu dilaksanakan (Dahlan, 2019; Karman, 2014; Moenawar, Priatna, \& Santoso, 2019). Kajian lainnya memotret aturan adat yang secara spesifik mengatur bagaimana pemilu seharusnya dijalankan yang berdampak pada tinggi dan rendahnya partisipasi politik masyarakat adat Baduy untuk datang ke TPS. Misalnya, adanya larangan bagi partai politik atau kandidat untuk melakukan 
POLITICON : Jurnal Ilmu Politik Vol.x No.x ; Hal 113 - 128

Website : http://journal.uinsgd.ac.id/index.php/politicon ISSN : 2685-6670 ( Online )

kampanye secara terbuka dan memasang alat peraga kampanye karena dianggap akan menciptakan perpecahan politik di tengah masyarakat. Bentuk Kampanye yang dibolehkan adalah kampanye secara personal dengan mengunjungi tiap-tiap rumah warga (silaturahmi politik) (Kurnia et al., 2010; Sofandi, 2014).

Dari sini nampak bahwa literatur yang ada hanya berkutat pada analisis partisipasi politik warga Baduy dalam pemilu dan faktor apa yang mendorong atau menghambat warga Baduy untuk datang ke TPS menggunakan hak pilihnya. Belum ada yang secara spesifik menjelaskan apa implikasi politik dari partisipasi politik masyarakat Baduy khususnya mengenai diskursus tentang representasi politik yang menjamin hadirnya pihak yang mampu memperjuangkan kepentingan masyarakat Baduy sebagai kelompok masyarakat minoritas di Kabupaten Lebak, Banten. Menggunakan konteks pemilu legislatif pada tahun 2009 dan 2014 sebagai tool untuk menjelaskan partisipasi politik warga Baduy dalam pemilu, saya berargumen bahwa partisipasi politik masyarakat adat baduy tidak berkorelasi terhadap bekerjanya ide representasi substansial. Representasi formal melalui proses elektoral tidak memberi dampak yang signifikan bagi kepentingan masyarakat Baduy. Warga Baduy tidak direpresentasikan oleh partai maupun kandidat di parlemen baik secara simbolik maupun substantif.

Dalam tulisan ini, partisipasi politik yang dimaksud adalah partisipasi dalam pemilu, yaitu aktivitas politik warga negara dalam menggunakan hak pilihnya memilih kandidat atau partai di tempat pemungutan suara (Norris, 2004). Partisipasi dan representasi politik secara konseptual cenderung dibedakan secara terpisah. Diskursus tentang partisipasi politik lebih banyak menyoroti pola, motif dan pembacaan terhadap dinamika atau fluktuasi tingkat partisipasi pemilih dalam konteks pemilu tertentu (Delwit, 2013; Solijonov, 2016). Sementara representasi politik mengkaji bagaimana representator mewakili kepentingan konstituen mereka melalui sejumlah kebijakan politik (Leston-Bandeira, 2012; Pitkin, 1967). Kendati demikian, 
beberapa sarjana mulai mengaitkan partisipasi politik dan representasi politik. Norris (2011) menyebut bahwa partisipasi politik dalam pemilu dan representasi politik sangat terkait dengan sistem pemilu. Sistem pemilu proporsional menghasilkan jumlah pemilih yang lebih tinggi dibandingkan sistem pemilu mayoritas sebab tidak adanya mekanisme wasted vote. Selain itu, sistem pemilu proporsional membuka peluang untuk memfasilitasi dan mengakomodasi kepentingan di antara berbagai kelompok etnis. Dengan kata lain, representasi etnis minoritas di parlemen sangat sulit terwujud dalam konteks pemilu mayoritas atau pluralitas.

Selain sistem pemilu, terdapat beberapa faktor yang dapat mengkondisikan insentif pemilih untuk datang ke TPS yaitu besaran dapil, frekuensi pemilihan, hukum pemilu dan syarat usia layak memilih (Norris, 2004). Kendati demikian, dalam konteks partisipasi memilih pada masyarakat adat Baduy, setting sosial budaya tidak bisa dinafikan dimana terdapat peran struktur adat yang turut mempengaruhi motivasi pemilih datang ke TPS (Karman, 2014).

Dalam demokrasi yang ideal, partisipasi pemilih tidak hanya selesai sebagai instrumen bagi warga negara datang ke TPS untuk mengantarkan partai atau kandidat mendapatkan kursi di parlemen yang dianggap dapat merepresentasikan kelompok tertentu. Bagaimana ide dan fungsi representasi politik yang dijalankan oleh partai atau kandidat menjadi penting untuk dilihat apakah mereka berdiri atas kepentingan konstituen yang diwakilinya dengan memperjuangkan kebijakan dan program tertentu atau cenderung abai dan bersikap pragmatis. Pitkin (1967) memaknai representasi sebagai menghadirkan yang absent. Lebih lanjut ia mengkategorikan representasi politik menjadi empat yaitu representasi formal, simbolik, deskriptif dan substantif. Representasi formal merujuk pada hadirnya otoritas dan akuntabilitas yang diberikan oleh konstituen kepada wakilnya. Representasi deskriptif menghendaki adanya wakil yang berasal dari kelompok yang diwakilkan (standing for). Representasi simbolik merujuk pada wakil 
POLITICON : Jurnal Ilmu Politik Vol.x No.x ; Hal 113 - 128

Website : http://journal.uinsgd.ac.id/index.php/politicon

ISSN : 2685-6670 ( Online )

merupakan simbol dari yang diwakili dengan mengklaim atas nama kelompok tertentu. Sementara representasi substantif mengacu pada tindakan wakil yang berusaha membawa kepentingan substantif yang diwakilinya ke ranah kebijakan publik (act for). Representasi substantif adalah yang paling ideal dibandingkan bentuk representasi lainnya.

Konsep representasi politik dari Pitkin menitikberatkan pada sang wakil yang hadir melalui proses pemilihan secara formal yaitu pemilu. Dalam demokrasi kontemporer yang ditandai oleh kompleksitas permasalahan representasi yang semakin rumit menyebabkan konsep representasi formal melalui elektoral yang dikonsepsikan oleh Pitkin kehilangan relevansinya. Kepercayaan pihak yang diwakili kerap memudar terhadap representator. Hal ini mendorong munculnya pihak-pihak lain (non-electoral) yang mengklaim berdiri atas nama kepentingan kelompok tertentu. Misalnya, individu, kelompok, atau organisasi masyarakat tertentu yang dianggap oleh masyarakat dapat mewakili dan memperjuangkan kepentingan mereka. Implikasinya, diskursus representasi kontemporer ditandai oleh adanya pergeseran dari representasi formal (electoral) ke representasi informal (nonelectoral) (Ekawati, 2016). Pergeseran ini bersifat dinamis, keduanya (representasi formal dan informal) dapat terdemarkasi secara jelas namun pada situasi politik tertentu kadang terdapat linkage diantara keduanya.

\section{METODE PENELITIAN}

Artikel ini menggunakan jenis penelitian kualitatif. Menurut Denzim dan Lincol (Moleong, 2010) penelitian kualitatif adalah penelitian yang menggunakan latar belakang alamiah dengan maksud menafsirkan fenomena yang terjadi dan dilakukan dengan jalan melibatkan berbagai metode yang ada. Pendekatan yang digunakan adalah studi kasus. Merujuk pada definisi Creswell (2010), riset penelitian studi kasus dianggap sebagai sebuah metodologi yaitu satu jenis desain dalam penelitian kualitatif yang dapat berupa objek penelitian dan juga hasil dari penelitian tersebut. Adapun studi kasus yang dimaksud adalah partisipasi politik masyarakat adat Baduy pada pemilu legislatif tahun 2009 dan 2014. 
POLITICON : Jurnal Ilmu Politik Vol.x No.x ; Hal 113 - 128

Website : http://journal.uinsgd.ac.id/index.php/politicon

ISSN : 2685-6670 ( Online )

Artikel ini menggunakan data sekunder melalui studi literatur dan dokumentasi yang merujuk pada bahan bacaan yang relevan terkait dengan partisipasi politik masyarakat adat baduy dan implikasinya terhadap representasi politik. Sumber informasi dari media online juga dijadikan sebagai referensi pada tulisan ini. Data yang diperoleh kemudian dipilih dan diseleksi dengan hanya mencantumkan bahan referensi yang relevan untuk menjawab rumusan masalah pada artikel ini.

\section{TEMUAN DAN PEMBAHASAN}

\section{Masyarakat Adat Suku Baduy: Setting Sosial dan Politik}

Masyarakat adat Baduy tinggal di lereng gunung Kendeng yang berada di Desa Kanekes, Kecamatan Leuwi Damar, Kabupaten Lebak, Banten. Mereka memilih untuk hidup mengasingkan diri dari interaksi dengan masyarakat lain. Hidup harmonis dengan alam dengan menjunjung tinggi aturan adat menjadi identitas mencolok yang membedakan mereka dengan masyarakat non Baduy. Suku Baduy adalah penghayat kepercayaan Sunda Wiwitan yang percaya pada roh nenek moyang. Suku Baduy pada umumnya terbagi menjadi dua yaitu Baduy Dalam dan Baduy Luar. Baduy Luar cenderung lebih dinamis dan terbuka terhadap interaksi dengan masyarakat luar. Warga Baduy tidak mengenyam pendidikan secara formal. Karena itu tingkat literasi masih sangat rendah. Mereka belum mampu membaca. Bahkan pegawai di Desa Kanekes tidak bisa baca tulis. Implikasinya, sulit menumbuhkan partisipasi aktif masyarakat Baduy terkait program yang digagas oleh pemerintah (Kurnia et al., 2010).

Masyarakat Baduy termasuk kelompok minoritas di Kabupaten Lebak yakni hanya 0,9 \% atau sekitar 11.699 jiwa dari seluruh jumlah populasi penduduk di Kabupaten Lebak, Banten yang mencapai 1.288.103 jiwa (Lebakkab.bps.go.id, 2018). Dalam berpolitik, keberadaan struktur adat sangat berpengaruh terhadap kehidupan warga Baduy. Mereka dipimpin oleh seorang Puun yang sangat disegani karena dianggap merepresentasikan hukum adat dan kebaikan alam. Puun dibantu oleh Jaro atau Kepala Desa yang 
POLITICON : Jurnal Ilmu Politik Vol.x No.x ; Hal 113 - 128

Website : http://journal.uinsgd.ac.id/index.php/politicon

ISSN : 2685-6670 ( Online )

dipilih berdasarkan tata cara adat, yaitu berdasarkan hasil musyawarah Puun. Kepemimpinan Jaro tidak dibatasi. Jaro memiliki peran ganda. Di satu sisi, Jaro bagian dari lembaga adat dibawah Puun yang bertanggung jawab mempertahankan tradisi dan hukum adat yang sudah mengakar kuat pada masyarakat Baduy. Di sisi lain, Jaro adalah jabatan seorang kepala desa dimana dalam struktur pemerintahan formal berada di bawah pemerintahan di atasnya yaitu kecamatan, pemerintah daerah, dan pemerintah pusat.

Salah satu bentuk pengaruh struktur adat terhadap cara masyarakat Baduy berpolitik adalah adanya nilai adat berupa Lunang atau Milu Kanu Meunang (ikut pada yang menang) yaitu sikap menerima dan taat kepada aturan pemerintah terlepas siapapun calon kandidat atau partai yang memenangkan kontestasi elektoral. Meskipun struktur adat sangat berperan dalam mengkonstruksi cara berpolitik masyarakat adat Baduy, tetapi mereka diberikan kebebasan hak politik untuk memilih calon kandidat atau partai. Tidak ada larangan, paksaan atau sanksi dari lembaga adat bagi masyarakat baduy yang memutuskan untuk datang atau tidak datang ke TPS. Hal ini tentu berbeda dengan kondisi masyarakat adat pada umumnya, dimana pilihan politik kerap dimobilisasi dan mengikuti pemilihan ketua adat (Karman, 2014).

Kendati demikian, ada beberapa hal yang harus diperhatikan terkait dengan pemilu. Misalnya, terdapat larangan kampanye terbuka dan pemasangan alat peraga kampanye di wilayah Baduy karena dianggap akan menimbulkan gesekan politik antara masyarakat Baduy. Partai atau kandidat yang ingin berkampanye diarahkan untuk berkunjung ke rumah warga secara personal. Selain aturan kampanye, ketika jadwal pemilu yang sudah ditetapkan oleh KPU setempat berbarengan dengan hari perayaan adat, maka masyarakat adat lebih memilih untuk mengikuti perayaan adat dibanding datang ke TPS. Hal ini pernah terjadi pada pemilu 2014 sehingga partisipasi masyarakat Baduy yang datang ke TPS sangat rendah (Saputra, 2017). 


\section{Membaca Partisipasi Politik Masyarakat Suku Baduy: Pileg 2009 dan 2014}

Sebagai bagian dari warga negara Indonesia, masyarakat Baduy memiliki hak untuk memilih dan dipilih. Meskipun peluang politik untuk dipilih dalam pemilu terbuka lebar, namun sampai saat ini belum ada calon kandidat yang berasal dari suku asli Baduy mengikuti kontestasi elektoral. Kendati demikian, mereka memiliki hak politik untuk memilih partai atau calon kandidat sesuai dengan kehendak mereka. Partisipasi politik dalam pemilu dapat dilacak pada pemilu tahun 1973 saat Orde Baru Soeharto berkuasa. Tingkat partisipasi masyarakat Baduy pada pemilu 1973 sangat rendah karena terkendala logistik dan jarak TPS yang jauh dari pemukiman yang tersebar di wilayah perbukitan dan hutan menyebabkan mereka kesulitan untuk datang ke TPS (Dahlan, 2019). Partai Golkar tampil sebagai pemenang di wilayah Baduy. Hal ini tidak lepas karena anggapan bahwa Golkar adalah partai pemerintah. Sementara, warga Baduy sangat memegang prinsip mengikuti dan taat terhadap pemerintah.

Tumbangnya Rezim Soeharto pada tahun 1998 telah menggeser sistem politik dari otoriter ke arah yang lebih demokratis. Banyak perubahan politik terjadi. Sistem kepartaian menjadi multi-partai dengan jumlah partai yang lebih bervariasi tanpa bayangan hegemoni partai Golkar. Selain itu, penyelenggaraan pemilu jauh lebih demokratis. Struktur peluang politik yang terbuka turut membentuk bagaimana masyarakat adat Baduy berpolitik khususnya terkait partisipasi politik dalam pemilu.

Pada pemilu legislatif tahun 2009, jumlah pemilih tetap (DPT) masyarakat Baduy sebanyak 6.334. Jumlah TPS yang tersedia hanya ada 2. Tingkat partisipasi pemilih sebanyak 1.362 (21.5\%) dengan suara tidak sah berjumlah 91 suara (6,5\%). Hasil pemilu memperlihatkan 4 partai terbesar yaitu Demokrat dengan 324 suara, Golkar memperoleh 300 suara, PPD sebanyak 267 suara dan PBR 253 suara.

Sementara pada pemilu legislatif 2014, jumlah TPS di Desa Kanekes diperbanyak dari semula 2 TPS menjadi 15 TPS. Hal ini sebagai respon atas 
rendahnya partisipasi memilih masyarakat Baduy karena jumlah TPS yang sangat minim. Penambahan TPS yang tersebar di berbagai wilayah di Desa Kanekes diharapkan dapat memberi insentif kepada masyarakat Baduy untuk datang ke TPS. Jumlah DPT mengalami peningkatan menjadi 7323 pemilih. Sebanyak 4.569 (62 \%) pemilih yang menggunakan hak pilihnya. Sementara jumlah suara tidak sah sebanyak 235 (5,1 \%) (Kpu.go.id).

Hasil pemilu legislatif 2014, di Desa Kanekes menempatkan Partai Golkar menduduki peringkat teratas dengan perolehan suara sebanyak 2.586 suara, disusul partai Gerindra sebanyak 955 suara, PDIP dengan 389 suara, Demokrat 300 suara dan PKB 235 suara (Kpu.go.id). Golkar berhasil tampil sebagai pemenang telak di Desa Kanekes. Hal ini tidak lepas dari hadirnya calon kandidat yang diusung oleh Partai Golkar memiliki keterikatan kekerabatan dengan suku Baduy. Keterikatan identitas yang sama ini dieksploitasi oleh kandidat untuk mendapatkan simpati pemilih dari masyarakat Baduy (Dahlan, 2019).

Perolehan hasil suara partai yang beragam pada pemilihan legislatif tahun 2009 dan 2014 mempertegas bahwa lembaga adat tidak memaksakan pilihan politik masyarakat Baduy untuk memilih salah satu partai atau kandidat tertentu. Dengan kata lain, masyarakat Baduy memiliki keleluasaan untuk menentukan hak pilihnya. Selain itu, dari dua pemilu ini menunjukkan adanya peningkatan partisipasi politik masyarakat Baduy dapat dilihat pada tabel 1.

Tabel 1. Daftar Anggota DPR RI dari Dapil I (Kabupaten Lebak dan Pandeglang)

\begin{tabular}{|c|c|c|c|c|c|}
\hline Periode & Anggota DPR & Partai & Periode & Anggota DPR & Partai \\
\hline \multirow{6}{*}{$\begin{array}{c}2009- \\
2014\end{array}$} & Achmad Dimyati & PPP & \multirow{6}{*}{$\begin{array}{c}2014- \\
2019\end{array}$} & $\begin{array}{l}\text { Vivi Sumantri } \\
\text { Jayabaya }\end{array}$ & Demokrat \\
\hline & Irna Narulita & PPP & & Beni Sudrajat & NasDem \\
\hline & $\begin{array}{l}\text { Iti Octavia } \\
\text { Jayabaya }\end{array}$ & Demokrat & & Abdul Halim & PPP \\
\hline & $\begin{array}{l}\text { Mamat Rahayu } \\
\text { Abdullah }\end{array}$ & Golkar & & Anda & Gerindra \\
\hline & Ratu Siti Romlah & Demokrat & & $\begin{array}{l}\text { Tb Ace Hasan } \\
\text { Syadzily }\end{array}$ & Golkar \\
\hline & $\begin{array}{l}\text { Tb. Dedi Suwendi } \\
\text { Gumelar }\end{array}$ & PDIP & & $\begin{array}{l}\text { Mochamad Hasbi } \\
\text { Asyidiki Jayabaya }\end{array}$ & PDIP \\
\hline
\end{tabular}

Sumber: Diakses dari website DPR RI (www.dpr.go.id) 
Pileg 2009 dan 2014 menghasilkan nama-nama anggota DPR RI dari dapil I untuk wilayah Lebak dan Pandeglang sebagaimana yang tercantum pada tabel diatas. Namun, berdasarkan penelusuran penulis, dari sejumlah deretan nama tersebut, tidak ada satupun anggota dewan yang berasal dari masyarakat asli suku Baduy, tidak juga memiliki kedekatan ikatan kekeluargaan dengan suku Baduy. Artinya, tidak ada representasi simbolik atau deskriptif (stand for) yang merujuk pada hadirnya anggota dewan sebagai representator yang berasal dari kelompok identitas masyarakat adat suku Baduy.

Jika ditelaah lebih detail, anggota dewan dari Dapil ini menjelaskan potret konfigurasi politik kekeluargaan (political family) di ranah parlemen. Achmad Dimyati dan Irna Nurulita adalah pasangan suami istri yang terpilih sebagai anggota DPR RI dari PPP. Mereka sukses membentuk jejaring kekuasaan yang cukup solid di wilayah Pandeglang. Sementara, Iti Octavia Jayabaya, Vivi Sumantri Jayabaya dan Mochamad Hasbi Jayabaya adalah satu keluarga dibawah naungan keluarga politik Jayabaya yang mendominasi panggung politik di Lebak dengan menggunakan mesin politik PDIP dan Demokrat. Hadirnya konfigurasi politik keluarga di ranah parlemen memberikan tantangan apakah mereka mampu berperan menghadirkan representasi substantif yang memperjuangkan kepentingan masyarakat adat Baduy melalui sejumlah produk kebijakan dan program tertentu. Ketika representasi secara simbolik tidak hadir, masyarakat adat Baduy menggantungkan harapan politik mereka pada anggota dewan terpilih agar memperjuangkan kepentingan adat meskipun bukan berasal dari Suku Baduy.

\section{Implikasi terhadap Representasi Politik: Kepentingan Adat yang Tersisih}

Partisipasi politik masyarakat Baduy dalam pemilu legislatif pada dasarnya merupakan bentuk mengekspresikan pilihan politiknya. Meski tingkat partisipasi cenderung rendah karena berbagai faktor teknis dan kultural, tetapi terjadi trend peningkatan jumlah partisipasi. Hal ini dapat 
dilihat pada pemilu legislatif 2009, angka partisipasi hanya 21\% sementara pada pemilu legislatif 2014 naik drastis menjadi 62 \%. Namun, partisipasi memilih masyarakat Baduy belum berkorelasi secara positif terhadap representasi politik. Dari periode pemilu ke pemilu, belum ada warga suku Baduy yang mencalonkan diri sebagai kandidat, sehingga mereka hanya memilih calon yang disediakan oleh partai politik. Implikasinya, suku Baduy tidak memiliki representasi politik secara formal-simbolik di parlemen.

Selain absennya representasi formal-simbolik di parlemen, representasi substantif yang menitikberatkan pada isu dan agenda kebijakan tertentu yang dijalankan oleh kandidat maupun partai politik khususnya di daerah pemilihan Baduy juga belum nampak. Padahal, masyarakat Baduy membutuhkan kepastian hukum terkait pengakuan dan jaminan negara bahwa eksistensi mereka tidak terancam oleh kepentingan ekonomi politik dari pihak tertentu. Di tahun 2019, masyarakat Baduy melalui Jaro (kepala desa adat Baduy) mendesak pemerintah merealisasikan undang-undang tentang Masyarakat Adat. RUU Masyarakat Adat sempat menjadi Prolegnas DPR RI pada tahun 2013 namun hingga saat ini belum ada kejelasan. Padahal, eksistensi masyarakat adat terus terancam khususnya terkait dengan kepemilikan tanah adat yang berpotensi memunculkan konflik agraria baik antara masyarakat adat dengan pihak swasta maupun negara. Di tataran daerah, berdasarkan keterangan Jaro, realisasi Perda Perlindungan Desa Adat masih alot (Satubanten.com, 2019). Berbeda dengan pemerintah daerah Provinsi Bali yang berinisiatif membentuk Perda Perlindungan Desa Adat di tengah ketidakpastian penerapan Undang-undang di tingkat nasional. Perda Perlindungan Masyarakat Adat Bali yang ditetapkan pada tahun 2019 tersebut telah mendapatkan persetujuan dari Kemenkumham.

Pada dasarnya, pemerintah daerah Kabupaten Lebak telah mengeluarkan Perda No 32 tahun 2001 tentang Perlindungan atas Hak Ulayat Masyarakat Baduy. Namun, tokoh masyarakat Baduy merasa bahwa Perda tersebut masih lemah dan belum cukup dalam melindungi eksistensi 
masyarakat Baduy. Hal ini dapat dilihat dari belum adanya pedoman pelaksanaan teknis untuk mengimplementasikan Perda tersebut. Selain itu, Perda tersebut dinilai sudah usang dan butuh pembaharuan karena permasalahan adat di masa depan kian kompleks. Segenap tokoh Baduy mendesak agar dibentuk Perda Gubernur Banten dan aturan yang lebih tinggi yaitu Undang-undang untuk memperkuat perlindungan terhadap masyarakat adat (Muhlisin, Ulumi, \& Humaeni, 2017).

Kekhawatiran masyarakat adat Baduy terkait ketidakpastian produk legislasi menyangkut jaminan perlindungan hak mereka dikarenakan semakin tahun terjadi pengurangan lahan hak ulayat dari awalnya seluas 5.156 hektare. Padahal masyarakat adat Baduy sangat menggantungkan hidup dari hutan dan lahan pertanian (Banten.antaranews.com, 2017). Selain itu, isu tentang pencantuman kolom agama di KTP masih menimbulkan polemik. Masyarakat adat Suku Baduy menganut kepercayaan Sunda Wiwitan. Selama ini mereka mengosongkan kolom agama sehingga muncul persepsi dari publik bahwa mereka dianggap tidak beragama. Padahal identitas kewarganegaraan adalah aspek yang sangat krusial. Karena itu, desakan untuk penerapan UU dan Perda Provinsi terkait perlindungan adat sangat rasional.

Anggota DPR RI dari Dapil Lebak yakni M. Hasbi Asyidiki Jayabaya pada tahun 2018 pernah berkunjung secara langsung ke masyarakat adat Suku Baduy untuk menjaring aspirasi terkait RUU tentang Hukum Adat (Dpr.go.id, 2018) bahkan setiap partai maupun kandidat yang melakukan kampanye dalam setiap periode pemilu sempat mendatangi langsung warga Baduy di Desa Kanekes, Lebak, tetapi kunjungan dan kampanye tersebut masih nihil, tidak berkorelasi terhadap kejelasan hadirnya produk kebijakan untuk melindungi eksistensi warga Baduy.

Kekosongan representasi formal melalui electoral pada akhirnya membuka peluang hadirnya aktor informal yang mengklaim berdiri atas nama kepentingan masyarakat Suku Baduy. Mereka adalah tokoh adat (Puun dan Jaro) yang memiliki concern memperjuangkan regulasi perlindungan 
POLITICON : Jurnal Ilmu Politik Vol.x No.x ; Hal 113 - 128

Website : http://journal.uinsgd.ac.id/index.php/politicon

ISSN : 2685-6670 ( Online )

masyarakat adat ke pemerintah meski sampai saat ini belum menemukan titik terang. Hal ini pula yang menyebabkan sebagian warga Baduy memandang bahwa pemilu tidak memberikan pengaruh yang signifikan (Kurnia et al., 2010). Partisipasi politik dalam pemilu hanya sebatas bentuk ketaatan mereka terhadap negara terkait ajakan untuk memilih karena mereka memegang teguh prinsip adat berupa Lunang-taat terhadap pemerintah.

\section{SIMPULAN}

Absennya representasi politik di parlemen baik secara simbolik (stand for) maupun substantif (act for) yang mengatasnamakan kepentingan hajat hidup masyarakat adat Baduy menjadi alasan mengapa produk kebijakan menyangkut perlindungan adat menemui jalan buntu. Hal ini juga mempertegas argumen bahwa partisipasi politik masyarakat adat Suku Baduy dalam pemilu legislatif tidak memiliki implikasi terhadap representasi politik. Kepentingan masyarakat adat Suku Baduy tidak terakomodasi oleh representasi formal melalui pintu elektoral baik oleh partai maupun calon kandidat. Partisipasi politik dalam pemilu cenderung dimaknai sebatas pada administrasi teknis kepemiluan.

Partai atau calon kandidat menyambangi masyarakat Suku Baduy sebatas pada kepentingan kampanye untuk merebut simpati pemilih. Namun setelah kontestasi elektoral usai, partai atau calon lenyap tanpa jejak. Padahal, dalam demokrasi representatif, partai atau anggota legislatif dituntut untuk menjalankan ide representasi yang mengedepankan kepentingan konstituen mereka. Political will dari partai sebagai institusi politik yang berfungsi melakukan rekrutmen politik dan menjalankan artikulasi kepentingan menjadi sangat penting. Apabila partai hanya menganggap Suku Baduy sebagai objek partisipasi dalam pemilu, dapat dipastikan representasi substantif berkaitan dengan hadirnya kebijakan yang akomodatif bagi masyarakat adat Baduy hanya sebatas isapan jempol semata. 


\section{DAFTAR PUSTAKA}

Andiraharja, D. G. (2020). Politik Hukum Pada Penanganan Tindak Pidana Pemilu. Khazanah Hukum, 2(1), 24-31.

Banten.Antaranews.Com. (2017). Masyarakat Baduy Tuntut Perlindungan Kearifan Lokal. Retrieved July 1, 2020, From Banten.Antaranews.Com Website: Https://Banten.Antaranews.Com/Berita/27669/MasyarakatBaduy-Tuntut-Perlindungan-Kearifan-Lokal

Creswell, J. W. (2010). Research Design Pendekatan Kualitatif, Kuantitatif, Dan Mixed. Yogyakarta: Pustaka Pelajar.

Dahlan, A. B. (2019). Orang Baduy Dalam Lintasan Politik Indonesia. Journal Ilmiah Rinjani, 7(1), 1-10.

Delwit, P. (2013). The End Of Voters In Europe? Electoral Turnout In Europe Since Wwii. Open Journal of Political Science, 3(01), 44.

Dpr.Go.Id. (2018). Kunjungi Suku Baduy, Komisi Ii Serap Masukan Ruu Hukum Adat. Retrieved July 1, 2020, From Dpr.Go.Id Website: Http://Dpr.Go.Id/Berita/Detail/Id/23025/T/Kunjungi+Suku+Baduy\%2c+Komisi+Ii+Serap+Masukan+Ruu+Hukum+Adat

Ekawati, E. (2016). Dari Representasi Politik Formal Ke Representasi Politik Non-Elektoral. Jurnal Penelitian Politik, 11(2), 8.

Heywood, A. (2014). Politik. Jakarta: Pustaka Pelajar.

Karman, K. (2014). Dialectic Of Baduy Community In Meaning Reality of General Election 2014. Jurnal Penelitian Komunikasi, 17(2).

Kurnia, A., Sihabudin, A., \& Yustianti, F. (2010). Saatnya Baduy Bicara: Lojor Teu Meunang Dipotong, Pondok Teu Meunang Disambung, Gunung Teu Meunang Dilebur, Lebak Teu Meunang Dirusak, Buyut Teu Meunang Dirobah. Bumi Aksara.

Lebakkab.Bps.Go.Id. (2018). Kabupaten Lebak Dalam Angka. Retrieved From Lebakkab.Bps.Go.Id

Leston-Bandeira, C. (2012). Parliaments' Endless Pursuit Of Trust: ReFocusing On Symbolic Representation. The Journal Of Legislative Studies, 18(3-4), 514-526.

Moenawar, M. G., Priatna, W. B., \& Santoso, H. (2019). Consciousness Raising Dan Partisipasi Politik Suku Baduy Di Era Digital (Tinjauan Awal). Jurnal Komunikasi Pembangunan, 17(1), 69-80. 
POLITICON : Jurnal Ilmu Politik Vol.x No.x ; Hal 113 - 128

Website : http://journal.uinsgd.ac.id/index.php/politicon ISSN : 2685-6670 ( Online )

Moleong, L. J. (2010). Metode Penelitian Kualitatif. Cetakan 27. Bandung: Pt Remaja Rosdakarya Offset.

Muhlisin, M., Ulumi, H. F. B., \& Humaeni, A. (2017). Kebijakan Pemerintah Daerah Dalam Perlindungan Masyarakat Adat Di Provinsi Banten: Studi Kasus Masyarakat Adat Baduy Dan Citorek. Jurnal Kebijakan Pembangunan Daerah, 1(1), 27-44.

Norris, P. (2004). Electoral Engineering: Voting Rules And Political Behavior.

Norris, P. (2011). Democratic Deficit: Critical Citizens Revisited. Cambridge University Press.

Pitkin, H. F. (1967). The Concept Of Representation (Vol. 75). Univ Of California Press.

Saputra, F. T. (2017). Partisipasi Politik Masyarakat Baduy Dalam Pemilihan Umum-(Studi Fenomenologi Partisipasi Politik Masyarakat Baduy Pada Pemilu 2014). Prosiding Magister Ilmu Komunikasi, 1(1).

Satubanten.Com. (2019). Warga Baduy Desak Pemerintah Segera Realisasikan Peraturan Tentang Masyarakat Adat. Retrieved July 1, 2020, From Satubanten.Com Website: Https://Satubanten.Com/Warga-BaduyDesak-Pemerintah-Segera-Realisasikan-Peraturan-Tentang-MasyarakatAdat/

Sofandi, D. (2014). Partisipasi Politik Masyarakat Suku Baduy Dalam Pemilihan Gubernur Provinsi Banten Periode 2012-2017. Uin Sunan Gunung Djati Bandung.

Solijonov, A. (2016). Voter Turnout Trends Around The World. Idea. 